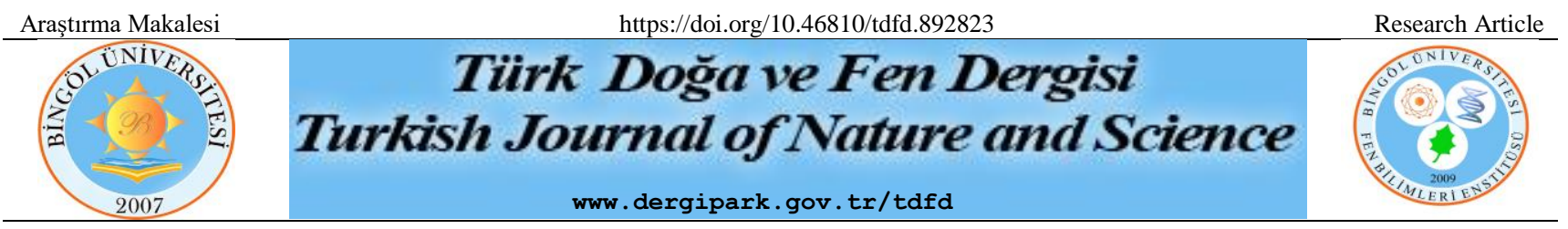

\title{
Çatılı Bina Modellerinde Binalar Arası Mesafenin ve Bina Yüksekliğinin Akış Yapısı Üzerindeki Etkisinin Deneysel ve Sayısal Olarak İncelenmesi
}

\author{
Deniz GÖLBAŞI ${ }^{1}$, Ertan BUYRUK ${ }^{2}$, Koray KARABULUT ${ }^{3 *}$ \\ ${ }^{1}$ Sivas Cumhuriyet Üniversitesi, Mühendislik Fakültesi, Makine Müh. Bölümü, Sivas, Türkiye \\ ${ }^{2}$ Sivas Cumhuriyet Üniversitesi, Mühendislik Fakültesi, Makine Müh. Bölümü, Sivas, Türkiye \\ ${ }^{3 *}$ Sivas Cumhuriyet Üniversitesi, Sivas Teknik Bilimler M. Y. O, Elektrik ve Enerji Bölümü, Sivas, Türkiye \\ Deniz GÖLBAŞI ORCID No: 0000-0003-0080-9996 \\ Ertan BUYRUK ORCID No: 0000-0002-6539-7614 \\ Koray KARABULUT ORCID No: 0000-0001-5680-0988
}

*Sorumlu yazar: kkarabulut@cumhuriyet.edu.tr

(Alınış: 08.03.21, Kabul: 03.08.21, Online Yayınlanma: 31.12.2021)

Anahtar
Kelimeler
Bina
aerodinamiği,
Parçacık
görüntülemeli
hı̈ ölçümü
(PIV),
Girdap

\section{Anahtar}

Bina

aerodinamiği,

Parçacık

hız ölçümü

Girdap
Öz: Aerodinamik, atmosferdeki zararlı gazların ve partiküllerin binaların etrafındaki akış yapısını etkileyerek bitki örtüsü ve binalar ile etkileşiminde önemli bir faktördür. Binaları etkileyen Rüzgâr etkileşimlerinin belirlenmesinde ve uygun tasarım parametrelerinin göz önüne alınmasında bina etrafındaki ayrılma bölgeleri ve girdap grupları büyük önem taşımaktadır. Bu çalışmada, çatılı-çapraz olarak yerleştirilmiş binalar arası mesafenin $6,25 \mathrm{~cm}$ olduğu $5 \mathrm{~cm} \times 5 \mathrm{~cm} \times 5 \mathrm{~cm}$ ve $5 \mathrm{~cm} \times 5 \mathrm{~cm} \times 10 \mathrm{~cm}$ boyutlarında ve $10 \mathrm{~cm}$ binalar arasi mesafe bulunan $5 \mathrm{~cm} \times 5 \mathrm{~cm} \times 10 \mathrm{~cm}$ boyutlarındaki binalar etrafındaki akış yapıları deneysel olarak Parçacık Görüntülemeli Hız Ölçüm (PIV) tekniği kullanılarak araştırılmıştır. Ayrıca, ayrı ayrı çatılı $5 \mathrm{~cm} \times 5 \mathrm{~cm} \times 5 \mathrm{~cm}$ ve $5 \mathrm{~cm} \times 5 \mathrm{~cm} \times 10 \mathrm{~cm}$ boyutlarındaki binaların etrafındaki akış analizi daimî, üç boyutlu, k- $\varepsilon$ türbülans modelli ANSYS Fluent programıyla sayısal olarak yapılmış ve ulaşılan sonuçlar deneysel sonuçlarla karşılaştırılmıştır. Çalışmada, akım çizgisi $\langle\psi\rangle$ ve hız vektörleri $<\mathrm{V}>$ dağılımları çizilmiş ve ortalama eşdeğer hız eğrileri faklı binalar arası mesafeler ve bina yükseklikleri için incelenmiştir. $6,25 \mathrm{~cm}$ ' lik binalar arası mesafeye göre $10 \mathrm{~cm}$ ' lik mesafede çapraz olarak yerleştirilen binanın ön bölgesindeki yukarı ve aşağı akış bölgelerinin mesafelerinde bir artış gözlemlenmiştir. Ayrıca, deneysel ve sayısal sonuçlar arasında en fazla \%3' lük bir farklılık bulunmuştur.

\section{Experimental and Numerical Investigation of the Effect of Distance Between Buildings and Building Height At Roofed Building Models}

\footnotetext{
Keywords

Building aerodynamic, Particle image velocimetry (PIV), Vortex
}

\begin{abstract}
Aerodynamics is an important factor in the interaction of harmful gases and particles in the atmosphere with vegetation and buildings by affecting the flow structure around buildings. Separation zones and vortex groups around the building are of great importance in determining the wind interactions affecting the buildings and considering the appropriate design parameters. In this study, flow structures around buildings with roof and placed diagonal, $6,25 \mathrm{~cm}$ distances between buildings with dimensions of $5 \mathrm{~cm} \times 5 \mathrm{~cm} \times 5 \mathrm{~cm}$ and $5 \mathrm{~cm} \times 5 \mathrm{~cm} \times 10 \mathrm{~cm}$ and $10 \mathrm{~cm}$ distances between buildings with dimensions of $5 \mathrm{~cm} \times 5 \mathrm{~cm} \times 10 \mathrm{~cm}$ were investigated as experimental by using Particle Image Velocimetry (PIV) technique. Besides, flow analysis vicinity buildings with roof and dimensions of $5 \mathrm{~cm} \times 5 \mathrm{~cm} \times 5 \mathrm{~cm}$ and $5 \mathrm{~cm} \times 5 \mathrm{~cm} \times 10 \mathrm{~cm}$ as numerical with ANSYS Fluent program having steady, $3 \mathrm{D}, \mathrm{k}-\varepsilon$ turbulence model was carried out separately and the obtained results were matched with those of experimentals. In the work, distributions of streamline $\langle\psi\rangle$ and velocity vectors $\langle\mathrm{V}\rangle$ were drawn and average equivalent velocity curves were researched for different distances between buildings and building heights. It was observed an increment in distances of the upstream and downstream regions at the front zone of the building, placed diagonally at a distance of $10 \mathrm{~cm}$ compared to the distance between the buildings of $6,25 \mathrm{~cm}$. Besides, it was found that there is at most a $3 \%$ differences between experimental and numerical results.
\end{abstract}




\section{GİRIŞ}

Aerodinamik, insanlar için sağlıklı ve konforlu bir çevre yaşamı oluşturulmasında ortamın ısıl şartlarını değiştiren rüzgârı hesaba katan bir iklim unsurudur. Çeşitli büyüklüklerdeki binalar ve baca yapıları, köprüler gibi birçok mühendislik uygulamaları üzerindeki akışlar araştırmacılar tarafından önemli olması sebebiyle özel bir inceleme konusu haline gelmiştir. Bina ve çevre mahalli arasında rüzgâr dolayısıyla meydana gelen ayrılma bölgeleri ve çeşitli girdap oluşumları binalar üzerinde etkili olan rüzgâr sistemlerinin belirlenmesinde ve en uygun tasarım değişkenlerinin dikkate alınmasında oldukça büyük bir öneme sahiptir. Rüzgârın binalar üzerindeki etkisiyle oluşan girdapların büyümesiyle meydana gelen titreşimler gürültü ve hasara sebebiyet verebilmektedir [1]. Tutar ve Oğuz [2] tek ve çift olarak yerleştirilmiş kare şeklindeki bina yapıları etrafındaki türbülanslı akış bölgelerini farklı rüzgâr açıları ve farklı geometrik düzenlemeler için sonlu hacim yöntemiyle incelemişlerdir. RNG türbülanslı model için bulunan sonuçları rüzgâr tüneli sonuçları ile kıyaslamışlardır. Sayısal ve deney sonuçlar arasındaki uyumun tek bina düzenlemesi için özellikle bina çatısı civarında olduğunu belirlemişlerdir.

Blocken ve ark. [3] Montreal şehir merkezinde belirledikleri bina etrafındaki kirlilik durumunu Rüzgâr tüneli deneyleriyle 2 farklı türbülans modelini kullanarak araştırmışlardır. Rüzgâr tüneli sonuçlarını CFD ile doğrulamışlardır. RANS ve LES türbülans modelleri kullanılarak çalışmalar yapılmış ve LES yaklaşımının her iki Rüzgâr yönü için CFD ve deneysel sonuçlarla uyum içerisinde olduğu tespit edilmiştir. Cheng ve ark. [4] yaptıkları çalışmada matematiksel olarak iyi tasarlanmış yüksek Re sayılı simülasyon yöntemini önererek kullanılan diğer modellerdeki hataları azaltmayı ve hesaplama yöntemini kolaylaştırmayı hedeflemişlerdir. Yüksek çözünürlüklü simülasyon yöntemi ile ortalama ve dalgalanan Rüzgâr basıncını nesnel ve kolay bir şekilde yeniden üretebilir ve yerinde ölçülen dağılımlar olarak model özelliklerini belirlemişlerdir. Huang ve ark. [5], bir plakanın aerodinamiği üzerinde Re sayısının, dönme oranının, kaldırma ve sürükleme katsayılarının etkilerini incelemişler ve en boy oranı daha büyük ve kalınlık oranı daha küçük olan plakanın kaldırma katsayısının, en boy oranı 2' den küçük olduğunda daha büyük olduğunu belirlemişlerdir. Aksi takdirde, kalınlık oranındaki artışla kaldırma katsayısının önce artmakta ve sonra azalmakta olduğunu saptamışlardır. Liu ve ark. [6] büyük girdap simülasyonları ile kasırga benzeri girdaplarda akış alanları üzerindeki Re etkilerini araştırmışlardır. Ortalama hızlar, hız dalgalanmalarının ortalama karekökünün yanı sıra momentumu sistematik olarak incelemişlerdir. Eğer, Re sayısı yeteri kadar yüksekse, radyal basınç değişimi ve merkezkaç kuvveti arasındaki momentuma ana denge yerine yakın yükseklikte bile ulaşılacağını bildirmişlerdir. Gölbaşı ve ark. [7] çatısız $5 \times 5 \times 5 \mathrm{~cm}$ ve 30 o eğimli çatılı $5 \times 5 \times 5 \mathrm{~cm}$ boyutlarında binalar etrafındaki akış yapılarını aralarında $13,75 \mathrm{~cm}$ boşluk olacak şekilde ikili olarak yerleştirilmesiyle Parçacık Görüntülemeli Hız (PIV) tekniğini kullanarak deneysel olarak incelemişlerdir. Gölbaşı ve ark. [8] yaptıkları bir diğer çalışmada, farklı yüksekliklere sahip iki bina modeli civarındaki akış özelliklerini üst görünüş olarak iki farklı ölçüm yüzeyi $(y / h=0,5$ ve $y / h=1)$ ve yan görünüş olarak ise $\mathrm{y} / \mathrm{h}=0,5$ yüzeyi için parçacık görüntülemeli hız ölçüm tekniğini kullanarak deneysel olarak araştırmışlardır. Çalışmalarında ayrıca, sonlu hacimler yöntemi ANSYS Fluent programiyla sayısal olarak da incelemişlerdir. Binaların köşelerinden ve kenarlarından gelen Rüzgârların ayrılmasının bir sonucu olarak çatı yüzeylerinde, binaların yan kenarları boyunca ön ve arkalarında ters akış bölgeleri oluştuğunu belirlemişlerdir. Daemei ve Eghbali [9], yüksek binaların türbülanslı bölgesinin uzunluğunu azaltmak için yuvarlatılmıș köșeler, oluklu köșeler ve girintili köşeler dahil olmak üzere aerodinamik modifikasyonlar yoluyla kare ve üçgen formlarında aerodinamik davranışın analizini gerçekleştirmişlerdir. 16 bina modeli üzerinde gerçekleştirilen Rüzgâr tüneli sayısal simülasyonuna benzer şekilde Autodesk akış tasarımı yazılımını kullanmışlardır. Yaklaşık $150 \mathrm{~m}$ yüksekliğe sahip 50 katlı yüksek binalar tasarlamak için üçgen şekle sahip modelin Rüzgâr yönüne bakan oluklu köşesinin aerodinamik modifikasyonu ile diğer modellere kıyasla en iyi aerodinamik davranışa sahip olduğunu saptamışlardır. Wheatley ve ark. [10] kat kat inşa etme ilkeleri olan origami ve kirigamiyi kullanarak tasarlanmış dinamik bina yapılarını dikkate alarak şiddetli Rüzgârlı darbeleri sönümlemek için daha kapsamlı bir yapı tasarımını gerçekleştirmişlerdir. Rüzgâr akışına bir açıda yönlerin sayısını artırarak ve bina cephelerinin boyutunu azaltarak, Rüzgâr akışına karşı doğrudan gövde boyutunun en aza indirilebileceğini ve Rüzgâr direncinin azaltılabileceğini belirlemişlerdir. Yan ve Li [11] aerodinamik düzenleme ile ikiz yüksek binalar arasındaki etkileşimin sonuçlarını incelemek amaciyla Rüzgâr tünelinde deneyler yapmışlardır. Çalışmada, Rüzgârın oluşturduğu tepkiyi, yerel basınç katsayılarını ve küresel aerodinamik yüklerle etkileşimin etkilerinin bir bütün olarak değerlendirilebilmesi için kontur çizimini sunmuşlardır. Sonuçlar, dinamik Rüzgâr yüklerinin ve tepkilerinin, ikiz kulelerin sıralı ve çapraz düzenlemelerinde önemli ölçüde arttığını ve en az değerdeki negatif basınç katsayısı değerlerinin, etkileşimli olmayanlardan yaklaşık olarak \%30 daha büyük olduğunu kanıtlamıştır.

Yapılar ve etraflarındaki Rüzgâr etkileşimleri, ayrılma bölgelerini ve çoklu girdap sistemlerini şekillendirmektedir. Oluşan ayrılma bölgeleri ve girdaplar, binalara etkiyen Rüzgâr kuvvetlerini belirlemede büyük bir öneme sahiptir. Ayrıca, binalardaki akış yapılarının bilinmesi hem tasarım açısından hem de zemin seviyesinde bulunan toz, toprak, yaprak, yağmur ve kar gibi parçacıkların girdap hareketleri ile yükselerek bina iç ortamına karışmasının engellenmesine katkı sağlamaktadır. $\mathrm{Bu}$ nedenle, bu çalışmada bina merkezleri arası mesafenin $6,25 \mathrm{~cm}$ olduğ $5 \mathrm{cmx} 5 \mathrm{~cm} \times 5 \mathrm{~cm}$ ve $5 \mathrm{~cm} \times 5 \mathrm{~cm} \times 10 \mathrm{~cm}$ boyutlarında ve $10 \mathrm{~cm}$ binalar aras1 mesafe bulunan $5 \mathrm{~cm} \times 5 \mathrm{~cm} x 10 \mathrm{~cm}$ boyutlarındaki çapraz olarak konumlandırılmış üç adet çatılı bina modelinin etrafındaki akış yapıları deneysel olarak Parçacık Görüntülemeli Hız tekniği (PIV) 
kullanılarak araştırılmıştır. Bunun yanı sıra, ayrı ayrı çatıl1 $5 \mathrm{~cm} \times 5 \mathrm{~cm} \times 5 \mathrm{~cm}$ ve $5 \mathrm{~cm} \times 5 \mathrm{~cm} \times 10 \mathrm{~cm}$ boyutlarındaki binaların etrafındaki akış analizi daimî, üç boyutlu, k- $\varepsilon$ türbülans modelli ANSYS Fluent programiyla sayısal olarak yapılmış ve ulaşılan sonuçlar deneysel sonuçlarla karşılaştırılmıştır. Başlangıçta deneylerde anlık hız alanlarına ulaşılmış ve sonra bu veriler kullanılarak akım çizgisi $\langle\psi\rangle$ ve hız vektörleri $\langle\mathrm{V}\rangle$ dağılımları çizilmiştir. Bununla birlikte, ayrıca ortalama eşdeğer hız eğrileri dağılımları her iki binalar arası mesafe ve bina yükseklikleri için analiz edilmiştir.

\section{MATERYAL VE METOT}

$\mathrm{Bu}$ çalışmada gerçekleştirilen deneyler, kapalı devre olarak işlem gören açık yüzeyli bir su kanalında Parçacık Görüntülemeli Hız Ölçme Tekniğiyle yapılmıştır. Kanal malzemesi olarak fiberglas malzeme kullanılmıştır. Kanal, iki adet su tankı ve tanklar arasına yerleştirilen test kanalı adı verilen şeffaf akrilik bir parçadan meydana gelmektedir.

Test kanalı $750 \mathrm{~mm}$ yüksekliğe, $1000 \mathrm{~mm}$ genişliğe ve $9000 \mathrm{~mm}$ uzunluğa sahiptir. Suyun su depoları arasındaki dolaşımı $15 \mathrm{~kW}$ gücünde santrifüj bir pompa ile sağlanmaktadır. Test bölgesinde farklı hızlarda deneyler gerçekleştirebilmek için santrifüj pompanın periyodu frekans kontrolü olan hız ünitesi vasitasıyla ayarlanabilmektedir. Pompa, çıkıştaki su tankından suyu emip, girişteki su tankına göndermektedir. Deneyler sırasında, test kanalında akışın sürekliliğini temin edebilmek için girişteki tankın çıkışına akış düzenleyici bir bal peteği biçiminde levha yerleştirilmiş ve giriş rezervuarının çıkışı ve test kanalının birleşimi arası oran olarak 2:1 daraltılarak bağlantı yapılmıştır. Test sisteminde giriş deposu aynı zamanda su bekleme odası olarak da hizmet vermekte ve buradan su akış düzenleme bölümüne geçerek test kanalına girmektedir. Sistemde suyu tank içerisindeki yabancı parçacık ve kirlerden ayıran filtrasyon sistemi bulunmaktadır. Bununla birlikte, su kanalı ile parçacık dolaşım sistemlerinin 1sıl temasını minumum düzeyde tutabilmek amaciyla laboratuvar $22{ }^{\circ} \mathrm{C}$ ' lik bir oda sıcaklığında tutulmuştur. Bunun yanı sıra, lazer 1şınını güneş ışı̆̆ından korumak için laboratuvar camları özel perdelerle kapatılmıştır. Test kanalının görünüşü Şekil 1'de gösterilmektedir.

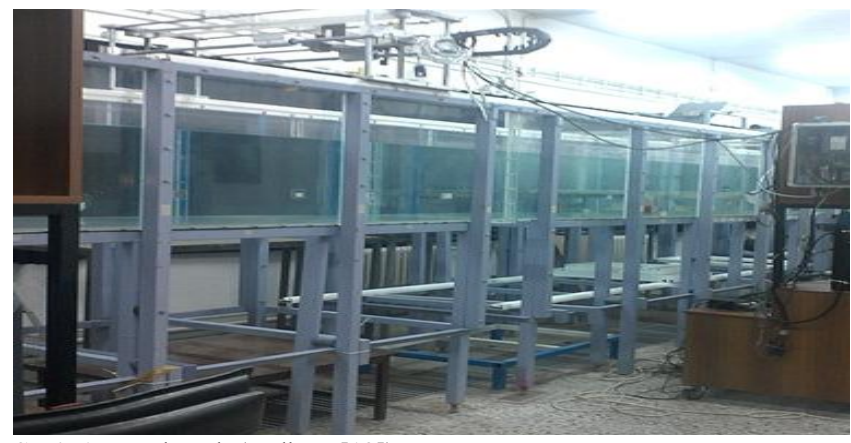

Şekil 1. Test kanalı (Gölbaşı [12])

Genel olarak, parçacık görüntülemeli hız ölçüm tekniği iki adımdan oluşur: hız ölçümünü görselleştirme ve görüntü işleme. Akışı takip edebilmek amacıyla akış alanına küçük boyutlu parçacıklar katılmaktadır. Katılan parçacıklar, ölçülecek yüzeydeki bir 1şık kaynağı ile kısa sürede iki kez aydınlatılır. Işık kaynağının ardışık aydınlatması (çoğunlukla lazer) arasında geçen zamansal fark, görüntülemenin ortalama akış hızına ve büyütme ölçeğine göre ayarlanır. Parçacıklar, iki aydınlatma arası geçen süre itibariyle yerel akış hızında hareket ederler. Parçacıkların saçtığı 1şık, 1şık katmanına dik yerleştirilen yüksek çözünürlüklü kamera ile algılanır ve iki kare üzerine kaydedilir. Elde edilen fotoğrafik PIV kayıtları daha sonra bir tarayıcı kullanılarak sayısallaştırılır ve bilgisayara aktarılır [9]. Şekil 2 (a), PIV' nin çalışma prensibini göstermektedir. Akış özelliklerini araştırmak için şeffaf akrilik malzemeden yapılmış 3 yapı modeli kullanılmıştır. Su kanalı içindeki test alanının şematik görünümü Şekil 2 (b)'de verilmiştir. Deneyler sırasında su kanalındaki su yüksekliği sabit $0.45 \mathrm{~m}$ olarak alınmıştır. Düzlem platformunun ön kenarı, akışın bozulmasını önlemek için pah kırma ile inceltilmiştir. Model, türbülans etkilerine karşı koruma sağlamak amacıyla kanalın girişinden $1,5 \mathrm{~m}$ uzağa monte edilmiştir. Deneyler, $210 \mathrm{~mm} \mathrm{~s}^{-11}$ lik bir serbest akış hızında gerçekleştirilmiştir.
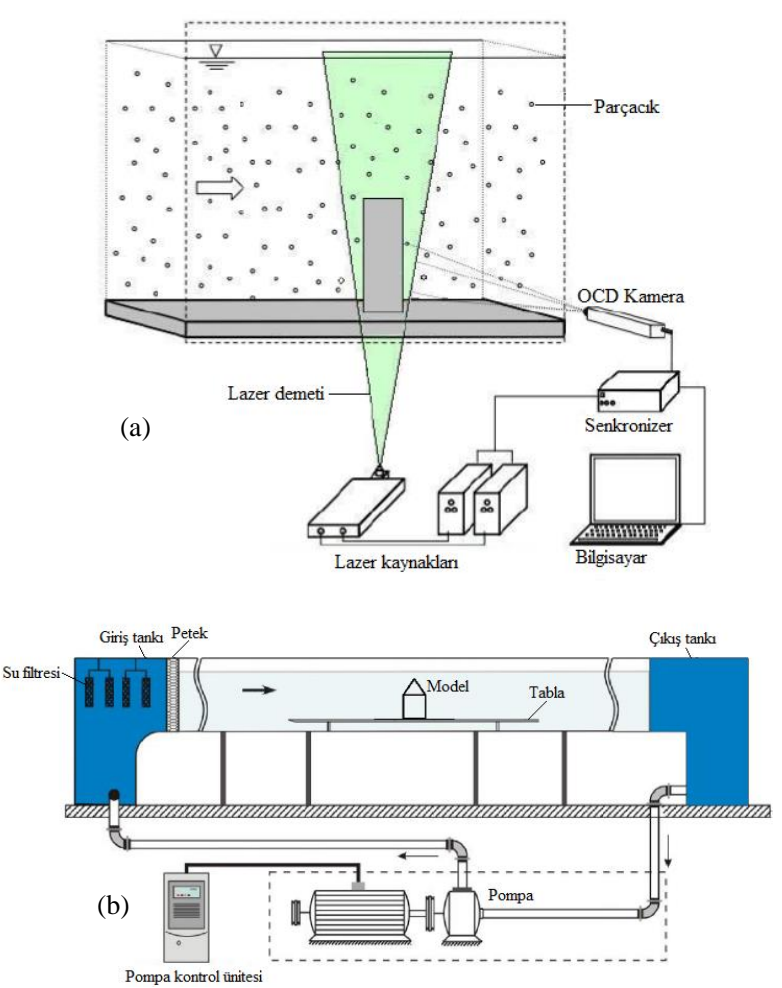

Sekil 2. (a) PIV çalışma prensibi (b) su kanalının șematik görünüșī (Gölbaşı [12])

\section{1. Üst Görünüş Ölçüm Yüzeyleri}

Şekil 3 (a)’ da gösterildiği gibi kamera kanalın karşısına yerleştirildiğinde, lazer, üst görünüş için binanın önüne yerleştirilmekte ve deneysel sistem, kameranın önünde $45^{\circ}$, lik bir eğimle ayna konumlandırılarak oluşturulmaktadır. Deneysel sistemde üst görünüş için kamera ve ayna yerleşimleri Şekil 3 (b)' de belirtilmektedir. Bununla birlikte, Şekil 3 (c)' de gösterilen simetri yüzeyi, üst görünüş için $\mathrm{y} / \mathrm{H}=0,5^{\prime}$ de alınmıştır. 

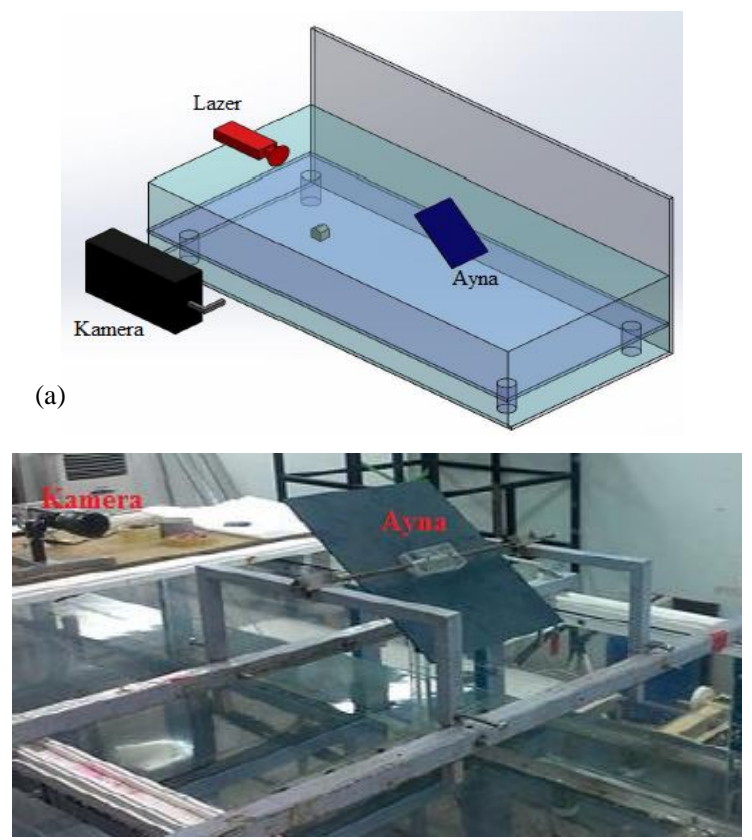

(b)

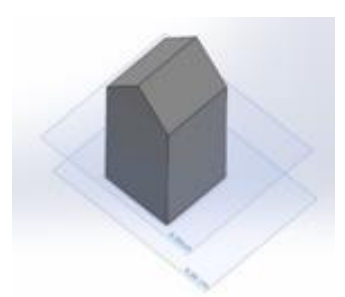

(c)

Şekil 3. (a) Üstten görünüş için tertibatın yerleşimi (b) deneysel sistemde üstten görünüş için kamera ve aynanın yerleşimi (c) üstten görünüş ölçüm yüzeyi (Gölbaş1 [12])

\section{SONUÇLAR VE TARTIŞMA}

Herhangi bir konum ve zamandaki hız, türbülans hız bileşenlerini ve ortalamaların toplamını içermektedir. Bu çalışmada, her bir ölçüm yüzeyi için ortalama hızlar ortalama olarak 500 görüntü için hesaplanmıştır. Akım çizgileri, herhangi bir anda yerel hız vektörlerinin tanjantı olan çizgilerin birleşimi olarak tanımlanmıştır. Bununla birlikte, girdap akış parçacıklarının dönmesinin bir ölçüsüdür. Her bir ölçüm yüzeyi için girdap değerleri, ortalama hızlar kullanılarak hesaplanmıştır.

Deneylerin sonucu olarak, binalar etrafında oluşan akış yapısı akım çizgileri $\langle\psi\rangle$ ve hız dağılımı $\langle\mathrm{V}\rangle$ olarak sunulmuştur. Elde edilen deneysel verilerde, hiz vektörleri akış dağılımı ve yönünü belirtirken, akım çizgileri anlı akış verilerinin anlaşılmasını kolaylaştırmaktadır. Ortalama eşdeğer hız eğrileri, türbülans sınır tabakanın etkisiyle oluşmuştur. Ayrıca, Şekil 4 (a) ve (b)' de sırasıyla birbirlerinden farklı mesafelerde yerleştirilmiş binaların şematik ve deneysel konumlanmaları gösterilmektedir.
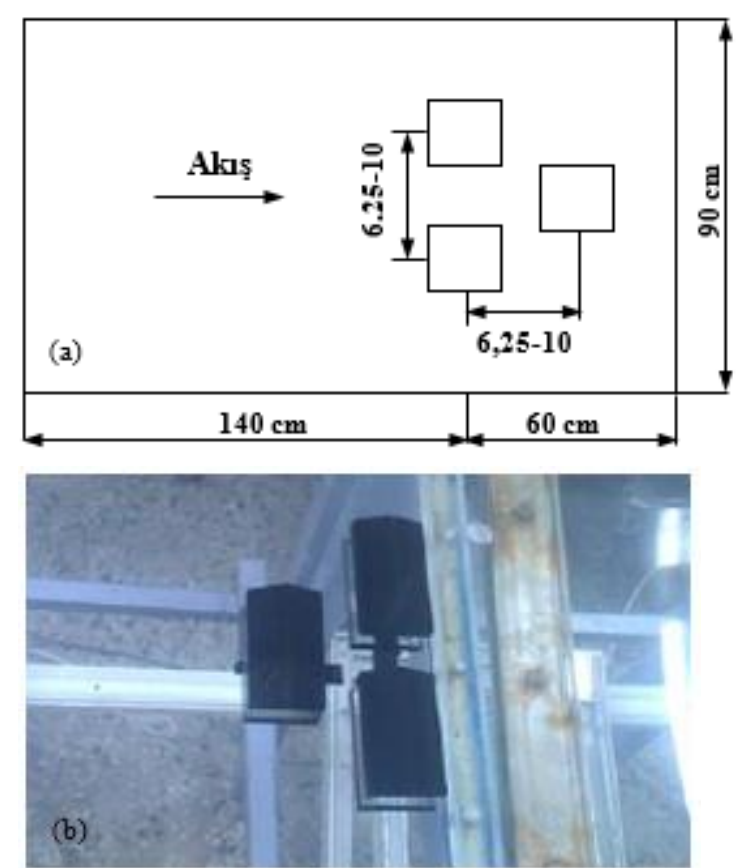

Şekil 4. Farklı yerleşim mesafeli üçlü bina modelleri gösterimi (a) şematik (b) deneysel

\subsection{Deneysel Sonuçlar}

Şekil 5 (a), (b)'de sırasıyla $5 \mathrm{~cm} \times 5 \mathrm{~cm} \times 5 \mathrm{~cm}$ boyutlarında $30^{\circ}$ çatı eğimli üç adet çatılı bina modelinin kanal içerisindeki plaka üzerine bina merkezleri arası mesafenin $6,25 \mathrm{~cm}$ olduğu durum için çapraz olarak yerleştirilmesiyle akım çizgileri $\langle\psi\rangle$ ve hı vektörleri $<\mathrm{V}>$ dağılımları incelenmiştir. Şekil.5 (a)'da görüldüğü gibi binaların yan kısımlarında ve bina arkalarındaki girdaplar birbirine simetrik bir yapıdadır. Arka kısma yerleştirilen binanın yan yüzeylerinde küçük girdap bölgeleri oluşmakla birlikte, meydana gelen girdaplar bölünmeden oluşmuştur. Üst bina modelinde, bina ön yüzeyinde Sab1 noktasından yukarıya doğru ayrılan akış model sol yan köşesinden ayrılarak bir $F_{1}$ girdap bölgesi oluşturmaktadır. $\mathrm{Bu}$ girdap merkezinin koordinatları $\mathrm{x}=$ $55,89 \mathrm{~mm}$ ve $\mathrm{z}=176,28 \mathrm{~mm}$ noktasındadır. Aşağıya doğru ayrılan akış, model sağ yan köşesinden yukarıya doğru yönlenmiştir. Binanın arka tarafında çatı kısmından dolayı ikincil bir ayrılmış akış bölgesi $\left(F_{2}\right)$ oluşmuştur. $\mathrm{Bu}$ girdap saatin tersi yönünde dönmekte olup, merkezinin koordinatları $\mathrm{x}=80,93 \mathrm{~mm}$ ve $\mathrm{z}=$ $135,18 \mathrm{~mm}$ noktasındadır. Üst bina ile alt bina arasında mesafe çok kısa olduğundan dolayı jet akış oluşmuştur. İki bina arasında oluşan bu jet akış, yüksek hızla arkadaki binaya çarparak Sab2 noktasından aşağıya doğru ve yukarıya doğru ayrılmaktadır. Üst bina arkasındaki akış yapısı incelendiğinde, jet akış etkisiyle binanın sağ yan tarafından yukarıya doğru yönlenmiş akışla binanın sol yan tarafından tekrar tutunan akış birleşmiştir. Bununla birlikte, üst bina arkasında ve arka bina üst yan kısmından başlayıp bina arkasına kadar yayılan büyük bir girdap bölgesi oluşmuştur. Oluşan bu büyük girdap bölgesi kendi içerisinde ikiye ayrılmıştır. Arka bina üst kısmında oluşan küçük girdap $F_{3}$ merkezinin koordinatlar1 $\mathrm{x}=117,248 \mathrm{~mm}$ ve $\mathrm{z}=164,94$ mm noktasında olup saat yönünde dönmektedir. Aynı 
zamanda, burada oluşan büyük girdap $\mathrm{F}_{4}$ merkezi $\mathrm{x}=$ $188,44 \mathrm{~mm}$ ve $\mathrm{z}=162,74 \mathrm{~mm}$ noktasında olup saat yönünde dönmektedir. Bununla birlikte, arka binanın alt yan kisminda $F_{3}$ ve $F_{4}$ girdabina simetrik olan $F_{6}$ ve $F_{5}$ girdabı oluşmaktadır. Büyük olan $\mathrm{F}_{5}$ girdap merkezinin koordinatlar1 $\mathrm{x}=179,181 \mathrm{~mm}$ ve $\mathrm{z}=57,97 \mathrm{~mm}$ noktasındadır. Büyük girdaptan ayrılan küçük $\mathrm{F}_{6}$ girdap merkezi $\mathrm{F}_{3}$ girdap merkezinin x koordinatı ile aynı olup $\mathrm{x}=117,248 \mathrm{~mm}$ ve $\mathrm{y}=61,48 \mathrm{~mm}$ noktasindadır. Bu iki girdabın uzunluğu eşit olup 160,33 mm olarak belirlenmiştir. Durma noktası olan $\mathrm{S}_{1}$ noktası $\mathrm{x}=248,36$ $\mathrm{mm}$ ve $\mathrm{z}=112,50 \mathrm{~mm}$ noktasındadır. Arka binanın Sab2 noktasından aşağı ayrılan akış yukarı tarafa ayrılan akışta olduğu gibi bir girdap bölgesi oluşturmuştur. $F_{7}$ girdabı olarak adlandırılan bu girdap, $F_{2}$ girdabıyla $x$ doğrultusunda aynı merkezde oluşmuş olup $\mathrm{x}=80,93$ $\mathrm{mm}$ ve $\mathrm{z}=92,19 \mathrm{~mm}$ noktasindadir. Alt tarafa yerleştirilen bina modelinde Sab3 noktasından aşağı ve yukarı ayrılan akış, üst taraftaki bina modelinin akış yapısına benzer olup aşağı ayrılan akış bina sağ yan köşesinden ayrılarak $\mathrm{F}_{8}$ girdap bölgesini oluşturmaktadır. $\mathrm{Bu}$ girdap merkezinin koordinatları $\mathrm{x}=55,31 \mathrm{~mm}$ ve $\mathrm{z}=$ $50,62 \mathrm{~mm}$ noktasındadır.
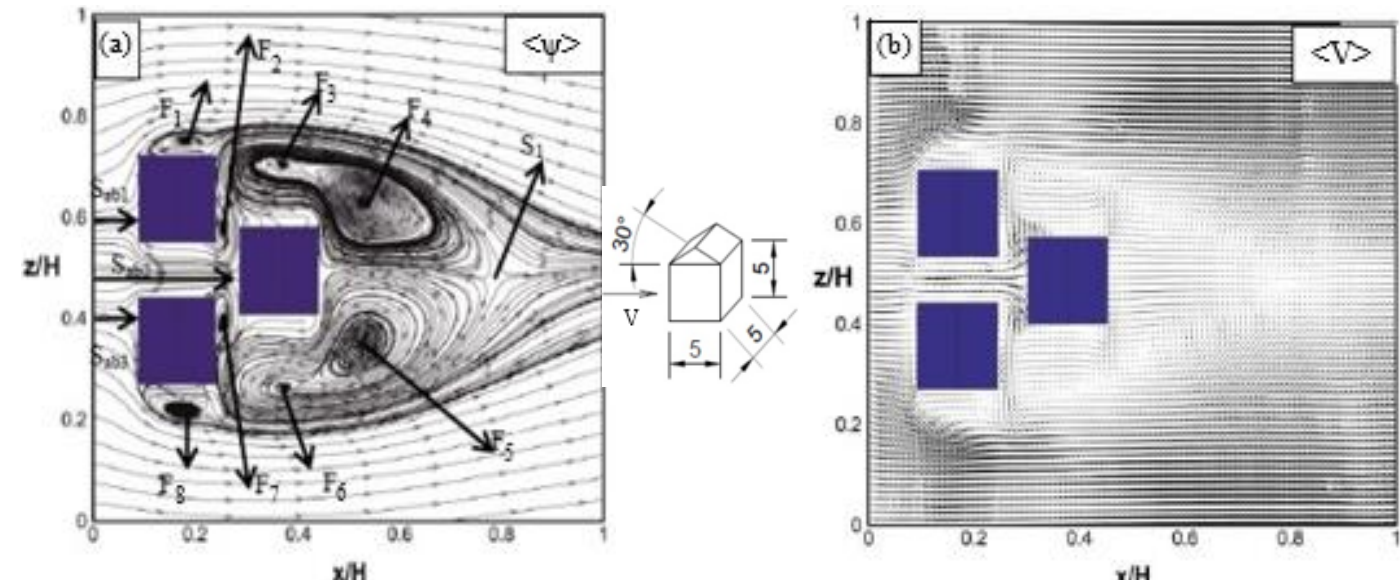

Şekil 5. Üçlü olarak yerleştirilmiş binalar aras $6,25 \mathrm{~cm}$ mesafe olan $5 \mathrm{~cm} x 5 \mathrm{cmx} 5 \mathrm{~cm}$ boyutlarındaki bina modelleri etrafindaki akış için $\mathrm{y} / \mathrm{H}=0,5$ simetri yüzeyi zaman ortalamalı (a) akım çizgileri $\langle\psi\rangle$, (b) hız dağılımı $<\mathrm{V}\rangle$

Şekil 5 (b)'de ölçüm sonucu elde edilen zaman ortalamalı hız alanlarında $<\mathrm{V}>$ görülebildiği gibi bina yakınlarında hız vektörlerinde azalma olmakta ve hız vektör uzunluklarının azalması nedeniyle bu bölgelerde hızlar azalmaktadır. Bina çevresinden uzaklaştıkça hız vektörlerinin bulunduğu alanlar ve hiz vektör uzunluklarının artması sebebiyle de hı değerleri artmaktadır. Özelikle bina üzerinde oluşan girdap üst bitim noktalarında hızın yükseldiği bölgeler görülebilmektedir. Ayrıca binaların arasında bir jet akış oluşmuş olup özellikle, iki bina arasındaki bölgelerde hızların yükseldiği görülmektedir.
Üçlü olarak çapraz şekilde yerleştirilen üç adet çatılı model için binalar arası mesafenin $6,25 \mathrm{~cm}$ olması durumunda $x$ ve y yönlerindeki ortalama eşdeğer hız eğrileri dağılımları sırasıyla Şekil 6 (a) ve (b)'de gösterilmektedir. Şekil 6 (a)' da öndeki ikili binanın üst yan ve arka bölgelerinde ve arka bina çevresinde oluşan ayrılmış akış bölgeleri (koyu mavi renkli kısımlar) görülmektedir. Arka binada oluşan ayrılmış akış bölgesi $\mathrm{x} / \mathrm{H}=0,7$ noktasına kadar uzanmaktadır.
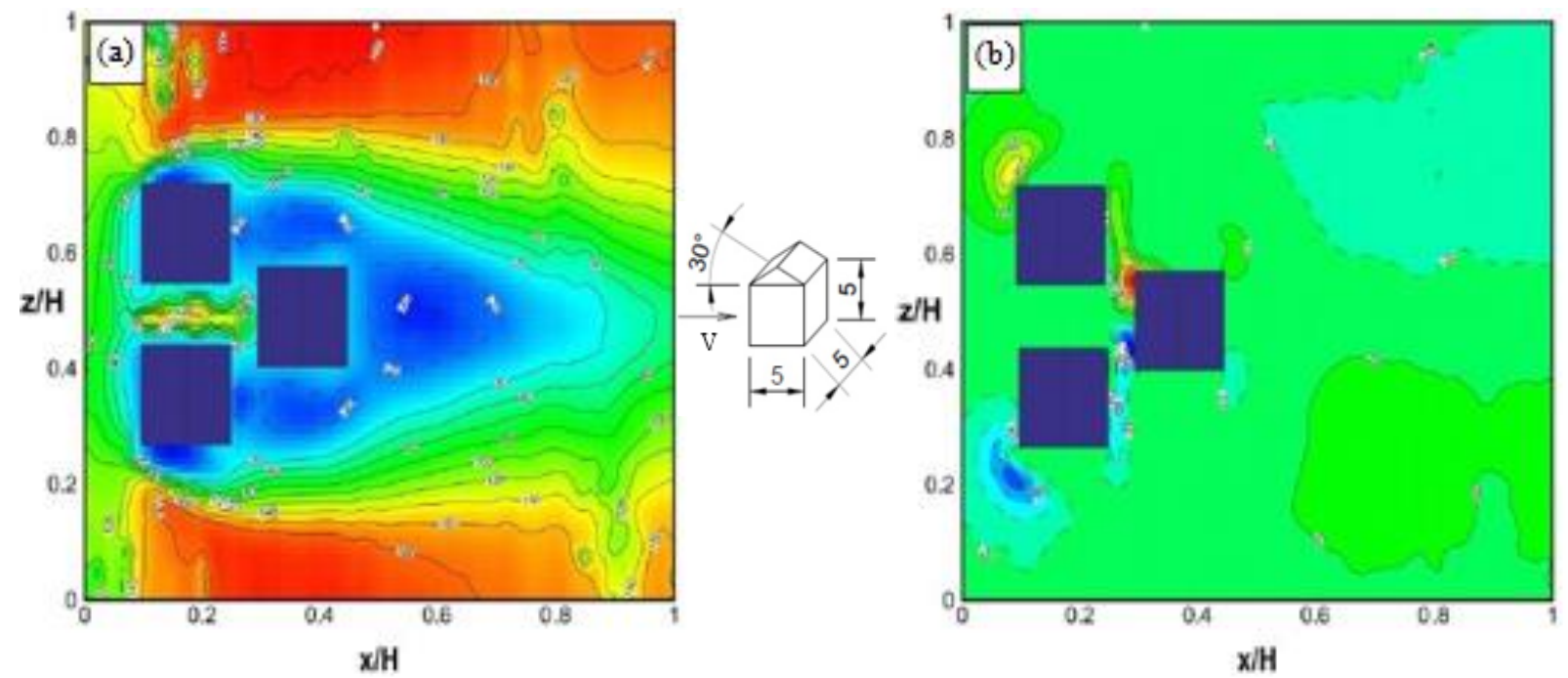

Şekil 6. Üçlü olarak yerleştirilen binalar arası $6,25 \mathrm{~cm}$ mesafe olan çatılı $5 \mathrm{~cm} x 5 \mathrm{cmx} 5 \mathrm{~cm}$ boyutlarındaki bina modelleri etrafındaki akış için y/H $=0,5$ simetri yüzeyi zaman ortalamalı (a) $<\mathrm{u}>$ hız dağılımı (b) $<\mathrm{v}>$ hız dağılımı 
İki bina arasındaki mesafenin çok az olması nedeniyle oluşan jet akış bu bölgede hız artışlarına sebep olmaktadır. Bununla birlikte, genel olarak zaman ortalamalı $<\mathrm{u}>$ eşdeğer hı dağılımları binalar çevresindeki akış yapısı açısından simetrik bir şekilde oluşmuştur. Şekil 6 (b)' de y yönündeki ortalama eş değer hız eğrileri incelendiğinde, bina önünde akış doğrultusunda yalnızca üst kısımlarda birbirlerine simetrik $\langle\mathrm{V}\rangle$ eşdeğer hız dağılımları oluşurken, alt kısımda oluşmadığı görülmektedir. Üst kısımdaki bina keskin kenarındaki köşede yukarı akım bölgesi oluşurken, alt kısımdaki bina keskin kenarının köşesinde ise aşağı akım bölgesi oluşmaktadır. Bununla birlikte, iki bina arasında herhangi bir hiz eğrisi meydana gelmezken, iki bina arkası ve çapraz duran bina ön bölgesinde yukarı ve aşağı akış bölgeleri oluşmuştur. Ayrıca, arka kısımda bulunan çapraz binanın hemen arkasında keskin köşelerin üst ve alt kısımlarında küçük yukarı ve aşağı akış bölgeleri meydana gelmiştir.

Boyutlar1 $5 \mathrm{~cm} 55 \mathrm{~cm} \times 10 \mathrm{~cm}$ ve bina merkezleri aras1 mesafenin $6,25 \mathrm{~cm}$ olduğu üç adet çatılı bina modeli için binalar etrafındaki zaman ortalamalı akım çizgileri $\langle\psi\rangle$ ve hız vektörleri $\langle\mathrm{V}\rangle$ dağılımları sırasıyla Şekil 7 (a) ve (b)'de sunulmaktadır. Şekil 7 (a)'da görüldüğü gibi binaların yan kısımlarında ve bina arkalarındaki girdaplar incelendiğinde birbirlerine simetrik bir yapıda oldukları görülmektedir. Bununla birlikte, üst bina modelinde bina ön yüzeyinde $S_{a b 1}$ noktasından yukarıya doğru ayrılan akış, model sol yan köșesinden ayrılarak bir F1 girdap bölgesi oluşturmaktadır. Bu girdap merkezinin koordinatları $\mathrm{x}=50,10 \mathrm{~mm}$ ve $\mathrm{z}=174,39$ $\mathrm{mm}$ noktasındadır. Aşağı ayrılan akış, model sağ yan köșesinden yukarıya doğru yönlenmiş ve bina arka kısmında çatı kısmından dolayı ikincil bir ayrılmış akış bölgesi meydana getirmiş̧ir. $\mathrm{Bu} \mathrm{F}_{2}$ girdabı saatin tersi yönünde dönmekte olup, merkezi $\mathrm{x}=78,46 \mathrm{~mm}$ ve $\mathrm{z}=$ $135,65 \mathrm{~mm}$ noktasındadır. Üst bina ile alt bina arasındaki mesafe çok kısa olduğundan dolayı jet akış oluşmuş ve iki bina arasında oluşan bu jet akış yüksek hızla arkadaki binaya çarparak $\mathrm{S}_{\mathrm{ab} 2}$ noktasından aşağ ve yukarıya doğru ayrılmıştır. Üst bina arkasındaki akış yapısı incelendiğinde, jet akış etkisiyle binanın sağ yan tarafından yukarıya doğru yönlenmiş akışla, binanın sol yan tarafından tekrar tutunan akış birleşmektedir. Ayrıca, üst bina arkasında ve arka bina üst yan kismından başlayıp bina arkasına kadar yayılan büyük bir girdap bölgesi oluşmaktadır. Büyük bir girdap bölgesi oluştuğu için girdap kendi içerisinde ikiye ayrılmıştır. Arka bina üst kısmında oluşan küçük girdap $\mathrm{F}_{3}$ ' ün merkezinin koordinatlar1 $\mathrm{x}=117,24 \mathrm{~mm}$ ve $\mathrm{z}=163,94 \mathrm{~mm}$ noktasında olup saat yönünde dönmektedir. Burada oluşan büyük girdap olan $\mathrm{F}_{4}$ ' ün merkezi $\mathrm{x}=168,74 \mathrm{~mm}$ ve $\mathrm{z}=145,74 \mathrm{~mm}$ noktasinda olup saat yönünde hareket etmektedir. Bununla birlikte, arka binanın alt yan kısmında $F_{3}$ ve $F_{4}$ girdaplarına simetrik olan $F_{6}$ ve $F_{5}$ girdapları oluşmuştur. Büyük olan $\mathrm{F}_{5}$ girdabının merkezi $\mathrm{x}=162,97 \mathrm{~mm}$ ve $\mathrm{z}=80,37 \mathrm{~mm}$ noktasındadır. Büyük girdaptan ayrılan küçük $F_{6}$ girdap merkezi $F_{3}$ girdap merkezinin $\mathrm{x}$ koordinatı ile aynı olup $\mathrm{x}=117,24 \mathrm{~mm}$ ve $\mathrm{y}=61,48 \mathrm{~mm}$ noktasındadır. Bu iki girdabın uzunluğu eşit olup 149,93 mm olarak belirlenmiştir. Durma noktası olan $\mathrm{S}_{1}$ noktasının koordinatları $\mathrm{x}=237,641 \mathrm{~mm}$ ve $\mathrm{z}=114,87 \mathrm{~mm}$ olarak belirlenmiştir. Arka binanın Sab2 noktasından aşağı ayrılan akış, yukarı tarafa ayrılan akışta olduğu gibi bir girdap bölgesi meydana getirmiştir. $\mathrm{F}_{7}$ girdabı olarak adlandırılan bu girdap $\mathrm{F}_{2}$ girdabıyla $\mathrm{x}$ doğrultusunda aynı merkezde oluşmuş olup $\mathrm{x}=78,46 \mathrm{~mm}$ ve $\mathrm{z}=135,65 \mathrm{~mm}$ noktasindadır. Alt tarafa yerleştirilen bina modelinde ise Sab3 noktasından aşağ 1 ve yukarı doğru ayrılan akış, üst taraftaki bina modelinin akış yapısına benzer olup, aşağı ayrılan akış bina yan sağ köşesinden ayrılarak $\mathrm{F}_{8}$ girdap bölgesini oluşturmuştur. $\mathrm{Bu}$ girdap merkezinin koordinatları ise $\mathrm{x}=54,731 \mathrm{~mm}$ ve $\mathrm{z}=51,56 \mathrm{~mm}$ noktasındadır.

Şekil 7 (b)'de gösterilen zaman ortalamalı hız alanları $<\mathrm{V}>$ grafiğinde bina yakınlarında hız vektörlerinde azalma gözlenirken, bu bölgelerdeki hızlar azalmaktadır. Bina çevresinden uzaklaştıkça, hız vektörlerinin bulunduğu alanlar ve hız değerleri artmaktadır. Bu durum, hiz vektör uzunluklarının artmasından anlaşılabilmektedir. Binalar arası bölgede ise jet akış nedeniyle hızın arttığı kısımlar ve akışın arka binaya çarptığ vektörlerinin yoğunluklarının arttığı bölgeler görülebilmektedir.
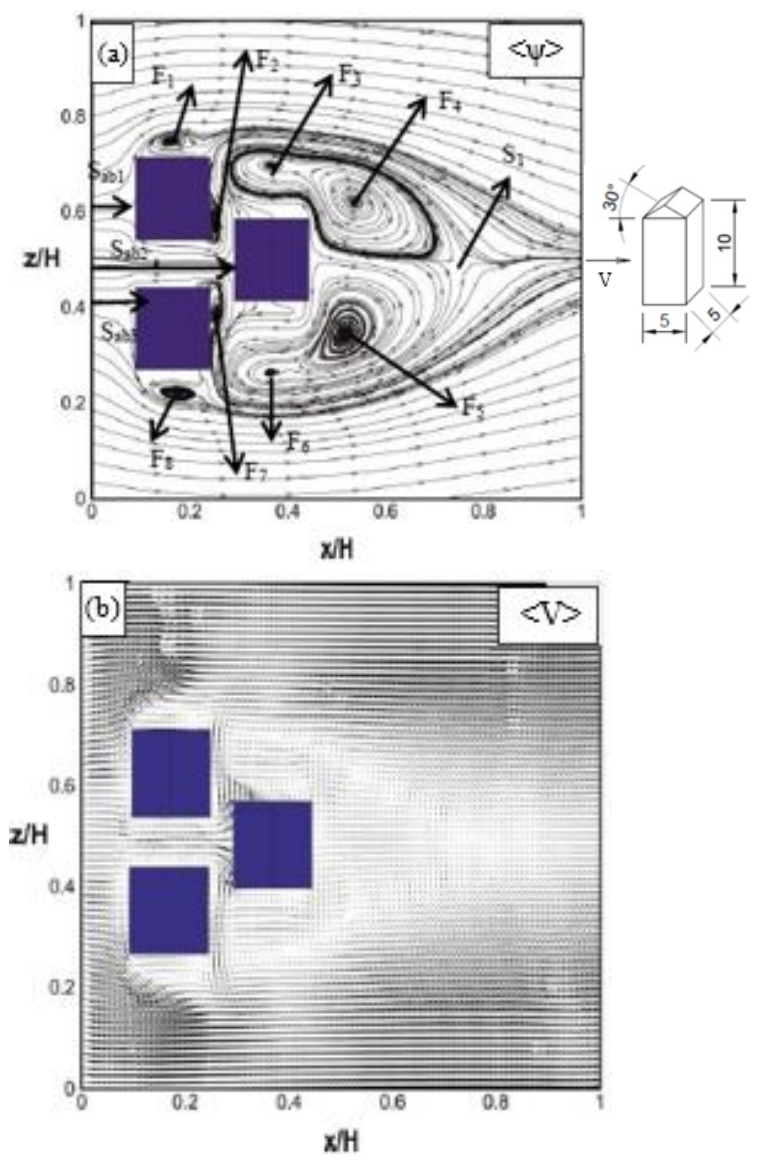

Sekil 7. Üclü olarak yerleștirilmiş binalar arası $6,25 \mathrm{~cm}$ mesafe olan $5 \mathrm{~cm} \times 5 \mathrm{~cm} \times 10 \mathrm{~cm}$ boyutlarındaki bina modelleri etrafindaki akış için $\mathrm{y} / \mathrm{H}=0,5$ simetri yüzeyi zaman ortalamalı (a) akım çizgileri $\langle\psi\rangle$, (b) hız dağılımı $<\mathrm{V}>$

Üçlü olarak çapraz şekilde yerleştirilen binalar arası mesafenin $6,25 \mathrm{~cm}$ olduğu $5 \mathrm{~cm} \times 5 \mathrm{~cm} \times 10 \mathrm{~cm}$ boyutlarındaki çatılı bina modellerinin etrafındaki ortalama eşdeğer hız eğrileri dağılımları $\mathrm{y} / \mathrm{H}=0,5$ simetri yüzeyinde $\mathrm{x}$ ve y yönleri için sırasıyla Şekil 8 (a) 
ve (b)'de sunulmaktadır. Öndeki çatılı ikili binanın yan ve arka kısımları ile arkadaki çapraz olarak yerleştirilmiş çatılı binanın yan ve arka bölgelerinde oluşan ayrılmış akış bölgeleri Şekil 8 (a)' da görülmektedir. Arka binada oluşan ayrılmış akış bölgesi $\mathrm{x} / \mathrm{H}=0,68$ noktasına kadar uzanmaktadır. Bununla birlikte, $5 \mathrm{~cm}$ yükseklikli çatılı binadakine benzer şekilde (Şekil 6 (a)) genel olarak $<\mathrm{u}>$ eşdeğer hız dağılımlarının binalar çevresindeki akış yapıs1 açısından simetrik bir şekilde oluştuğu söylenebilmektedir. Bununla birlikte, Şekil 6 (a)' daki çatılı kısa modele göre akış yapısı çok az farklılık göstermektedir. Ayrıca, Şekil 8 (b)' de verilen y yönündeki ortalama eşdeğer hız eğrileri incelendiğinde Şekil 6 (b)' deki eşdeğer hız eğrileri ile benzer akış yapısı oluştuğu görülmektedir.
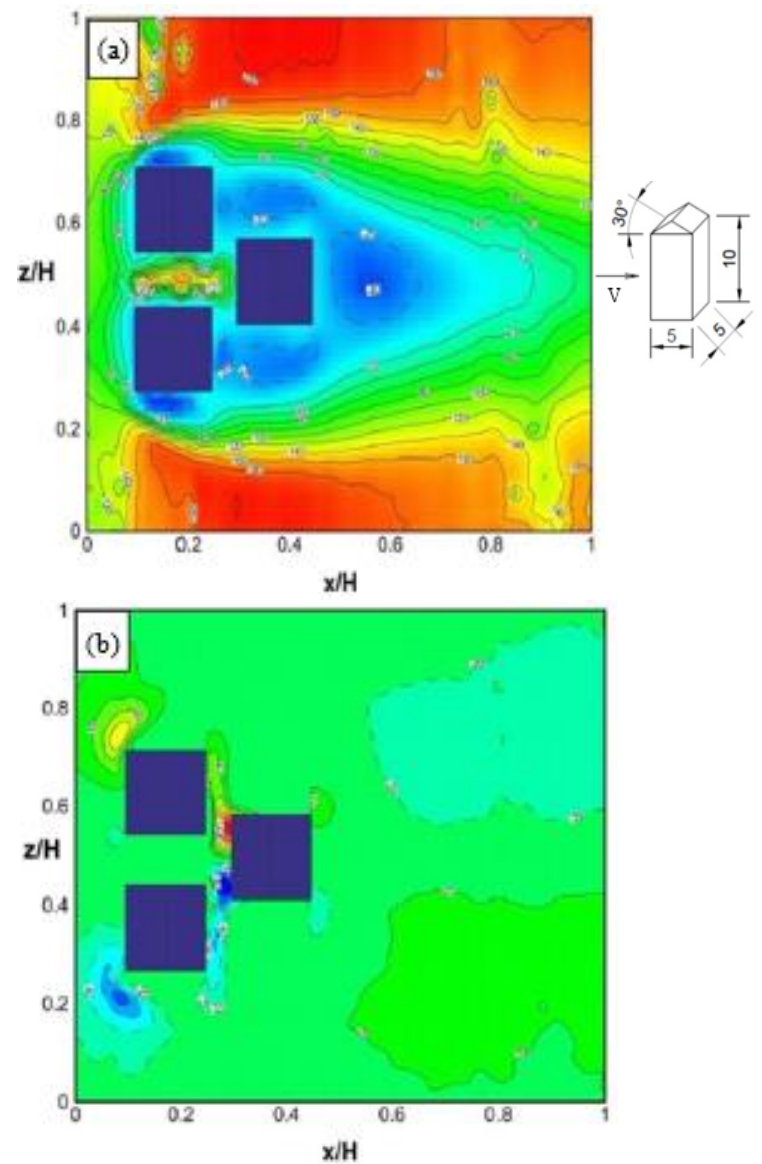

Şekil 8. Üçlü olarak yerleştirilen binalar arası $6,25 \mathrm{~cm}$ mesafe olan $5 \mathrm{~cm} \times 5 \mathrm{~cm} \times 10 \mathrm{~cm}$ boyutlarındaki çatılı bina modelleri etrafındaki akış için $\mathrm{y} / \mathrm{H}=0,5$ simetri yüzeyi zaman ortalamalı (a) $<\mathrm{u}>$ hız dağılımı (b) $<\mathrm{v}>$ hız dağılımı

Şekil 9 (a) ve (b)' de sirasıyla boyutları $5 \mathrm{~cm} \times 5 \mathrm{~cm} \times 10 \mathrm{~cm}$ ve bina merkezleri arası mesafenin $10 \mathrm{~cm}$ olduğu üç adet çatılı bina modeli için binalar etrafındaki zaman ortalamalı akım çizgileri $\langle\psi\rangle$ ve hız vektörleri $\langle\mathrm{V}\rangle$ dağılımları gösterilmektedir. Şekil 9 (a)'da görüldüğü gibi binaların yan kısımlarında ve bina arkalarındaki girdaplar incelendiğinde birbirlerine simetrik bir yapıda olmadıkları dikkati çekmektedir. $\mathrm{Bu}$ duruma binalar arası mesafenin artışıyla gelen akışın binaların köșe ve kenarlarından ayrılması sonucu binanın yan duvarları ve arka kısmında oluşan ters akış bölgeleri neden olmaktadır ki buralarda akış hızları azalmaktadır. Alt taraftaki bina modelinde, üst taraftakinden farklı olarak alt yan ve arka kısmında tek bir girdap bölgesi oluşmuştur. Üst bina modelinin bina ön yüzeyinde Sab1 noktasından yukarı doğru ayrılan akış için model sol yan köşesinden ayrılarak birbirleriyle bağlantılı iki girdap bölgesi meydana getirmiştir. $F_{1}$ ve $F_{2}$ olarak adlandırılan girdap merkezlerinden $\mathrm{F} 1$ için koordinat merkezi $\mathrm{x}=$ $55,88 \mathrm{~mm}$ ve $\mathrm{z}=194,70 \mathrm{~mm}$ noktasında iken $\mathrm{F}_{2}$ için $\mathrm{x}=$ $92,34 \mathrm{~mm}$ ve $\mathrm{z}=189,98 \mathrm{~mm}$ olarak belirlenmiştir. Aşağ ayrılan akışta model sağ yan köşesinden akışın bir kısmı küçük bir girdap oluştururken, bir kısmı da ayrılmadan yukarıya doğru akışına devam edip $F_{1}$ girdabının tekrar birleşme noktasındaki akışla birleşmektedir. Bu noktada $\mathrm{S}_{1}$ durma noktası meydana gelmiş olup, bu noktanın merkezi $\mathrm{x}=120,70 \mathrm{~mm}$ ve $\mathrm{z}=178,64 \mathrm{~mm}$ olarak belirlenmiştir. Bununla birlikte, $\mathrm{S}_{1}$ durma noktasının alt kısmında $F_{3}$ girdabı oluşmuştur. $F_{3}$ girdap merkezinin koordinatlar1 ise $\mathrm{x}=108,55 \mathrm{~mm}$ ve $\mathrm{z}=164 \mathrm{~mm}$ noktasında olup saat yönünün tersine dönmektedir. İki bina arasında oluşan jet akış yüksek hızla arkadaki binaya çarparak $S_{a b 2}$ noktasından aşağ1 ve yukarı doğru ayrılmaktadır. Arka binanın üst yan, alt yan ve üst köşe bölgelerinde birbirlerine simetrik olmayan girdap bölgeleri meydana gelmektedir. Üst yan ve arka bölgede oluşan girdap bölgeleri eşit boyutlarda bölünerek $\mathrm{F}_{4}$ ve devamında $F_{5}$ girdap bölgelerini oluşturmuştur. $F_{4}$ girdap merkezinin koordinatları $\mathrm{x}=161,79 \mathrm{~mm}$ ve $\mathrm{z}=156,91$ mm noktasında olup saat yönünde dönmektedir. Bununla birlikte, $\mathrm{F}_{5}$ girdap merkezinin koordinatları ise $\mathrm{x}=$ $200,57 \mathrm{~mm}$ ve $\mathrm{z}=148,88 \mathrm{~mm}$ noktasinda olup saat yönünde dönmektedir. Alt yan ve arka bölgede tek bir $F_{6}$ girdabı oluşmuş olup merkez koordinatları $\mathrm{x}=204,62$ $\mathrm{mm}$ ve $\mathrm{y}=67,15 \mathrm{~mm}$ noktasında olup saat yönünün tersine dönmektedir. Şekilden de görülebildiği gibi alt kısma yerleştirilen bina modelinde akış yapısı, üst bina modelindeki akış yapısından farklıdır. Alt tarafa yerleştirilen bina modelinde Sab3 noktasından aşağıya ve yukarıya doğru ayrılan akışlar, üst taraftaki bina modelinin akış yapısına simetrik bir akış yapısı oluşturmamış olup, yukarı ayrılan akışın bir kısmı ayrılmadan aşağıya doğru hareket etmektedir. Akışın diğer kısmı, binanın arka kısmında tek bir girdap bölgesi oluşturmuştur. $\mathrm{Bu}$ girdap noktası olan $\mathrm{F}_{7}$ ' nin merkez koordinatlar1 $\mathrm{x}=102,76 \mathrm{~mm}$ ve $\mathrm{z}=66,68 \mathrm{~mm}$ noktasındadır ve saat yönünde dönmektedir. Bina ön yüzünden aşağı ayrılan akış, bina sağ yan köşesinden ayrılarak $F_{8}$ ve $F_{9}$ girdap bölgesini oluşturmuştur. $F_{8}$ ve $\mathrm{F}_{9}$ girdap merkezlerinin koordinatları sirasıyla $\mathrm{x}=90,61$ $\mathrm{mm}$ ve $\mathrm{z}=37,39 \mathrm{~mm}$ ve $\mathrm{x}=65,14 \mathrm{~mm}$ ve $z=34,08 \mathrm{~mm}$ noktalarında belirlenmiştir. Bu girdabın sağ yanında $\mathrm{S}_{3}$ durma noktası oluşmuş olup, merkezi $\mathrm{x}=119,55 \mathrm{~mm}$ ve $\mathrm{z}=46,37 \mathrm{~mm}$ noktasındadır. Şekil 9 (b)'de zaman ortalamalı hız dağılımında $<\mathrm{V}>$ jet akış etkisi ile hızın yüksek yoğunluklu olduğu alanlarda vektörlerin s1k olduğu bölgeler görülmektedir. Özellikle, iki bina arası bölgede ve akışın bina yüzeylerine çarptığı kısımlarda hızlar nedeniyle vektörlerin yoğunlukları fazladır. Bununla birlikte, binaların yan ve arka kısımlarında girdapların olduğu yerlerde vektör yoğunluklarında azalmalar görülmektedir. Bu kısımlar akış hızının az olduğu bölgeleri temsil etmektedir. 

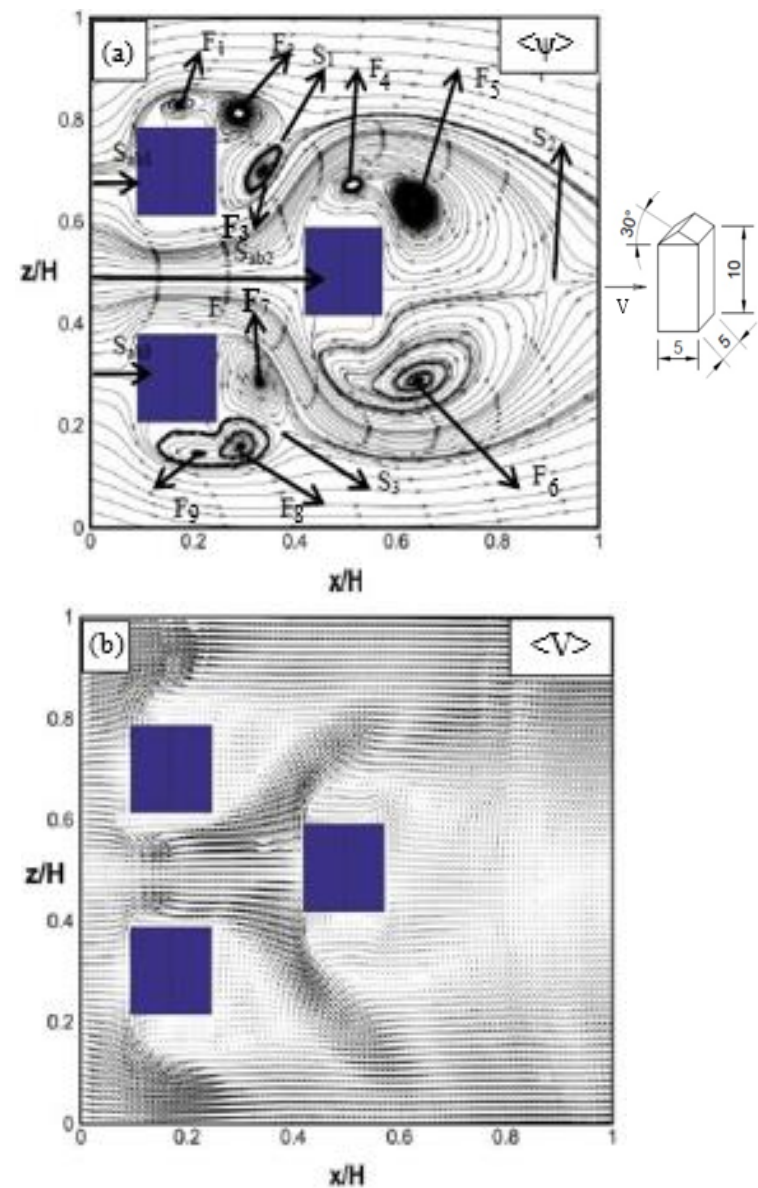

Şekil 9. Üçlü olarak yerleştirilmiş binalar arası $10 \mathrm{~cm}$ mesafe olan $5 \mathrm{~cm} \times 5 \mathrm{~cm} \times 10 \mathrm{~cm}$ boyutlarındaki bina modelleri etrafındaki akış için $\mathrm{y} / \mathrm{H}=0,5$ simetri yüzeyi zaman ortalamalı (a) akım çizgileri $\langle\psi\rangle$, (b) hız dağılımı $<\mathrm{V}>$

Şekil 10 (a) ve (b)'de sırasıyla üçlü olarak çapraz şekilde yerleştirilen ve binalar arası mesafenin $10 \mathrm{~cm}$ olduğu $5 \mathrm{~cm} \times 5 \mathrm{~cm} \times 10 \mathrm{~cm}$ boyutlarındaki çatılı bina modellerinin etrafındaki ortalama eşdeğer hız eğrileri dağılımları $\mathrm{y} / \mathrm{H}$ $=0,5$ simetri yüzeyinde $\mathrm{x}$ ve y yönleri için sırasıyla verilmektedir. Şekil 8 (a)' daki binalar arası mesafenin $6,25 \mathrm{~cm}$ olduğu durumla karşılaştırıldığında Şekil 10 (a)' da jet akış bölgesinin oldukça genişlediği ve çapraz olarak yerleştirilen bina çevresindeki ayrılmış akış bölgesinin küçüldüğü görülmektedir. Bununla birlikte, aynı durum Şekil 10 (b)' deki y yönündeki ortalama eşdeğer hız dağılımları için de geçerli olmakla beraber kanal girişindeki ikili binaların üst ve alt kısımlarındaki bölgelerinde yukarı ve aşağı akış bölgeleri meydana gelmiştir. Ayrıca, çapraz bina ön bölgesindeki yukarı ve aşağı akış bölgelerinin mesafeleri artmıştır.

\subsection{Sayısal Sonuçlar}

Sayısal çalışma, üç boyutlu ve daimi olarak k- $\varepsilon$ türbülans modelli sonlu hacimler yöntemi olan ANSYS Fluent bilgisayar programı kullanılarak yapılmıştır. Çalışmada, tek $5 \mathrm{~cm} \times 5 \mathrm{~cm} \times 5 \mathrm{~cm}$ ve $5 \mathrm{~cm} \times 5 \mathrm{~cm} \times 10 \mathrm{~cm}$ boyutlu çatılı bina için elde edilen deneysel çalışma sonucunun (PIV), sayısal çalışmadan elde edilen sonuçlarla karşılaştırılması amaçlanmıştır.
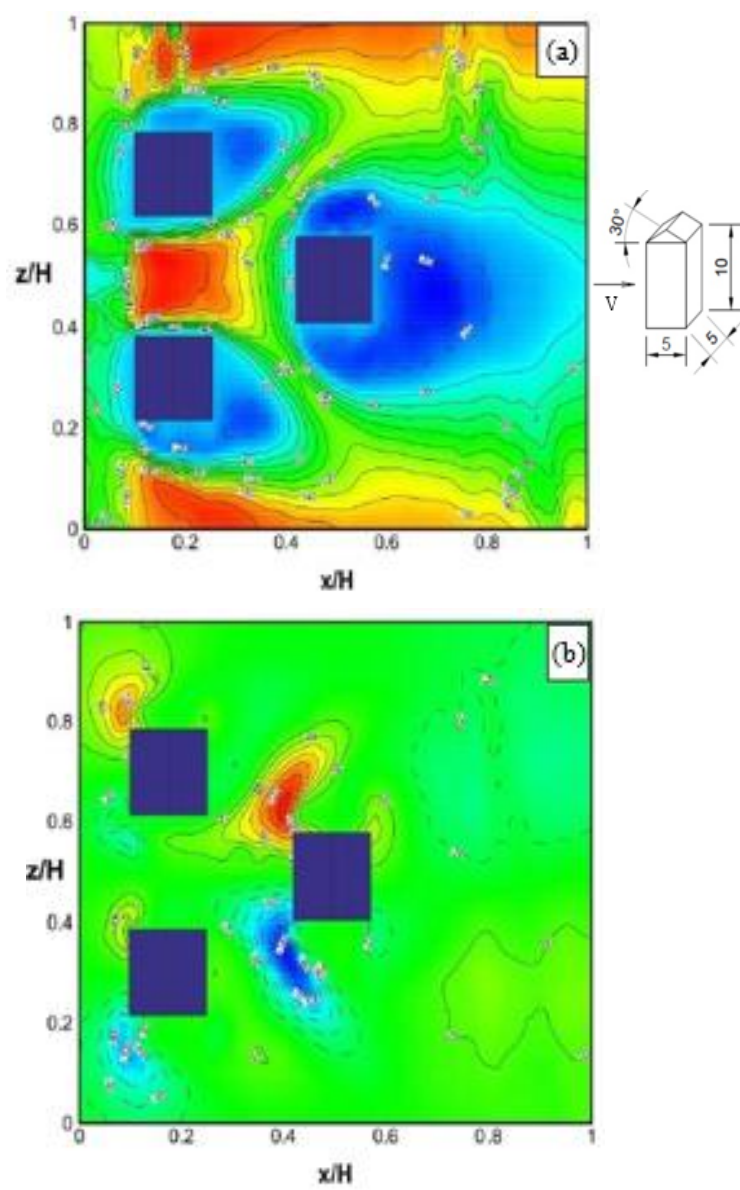

Şekil 10. Üçlü olarak yerleştirilen binalar arası $10 \mathrm{~cm}$ mesafe olan $5 \mathrm{~cm} \times 5 \mathrm{~cm} \times 10 \mathrm{~cm}$ boyutlarındaki çatılı bina modelleri etrafındaki akıs için $\mathrm{y} / \mathrm{H}=0,5$ simetri yüzeyi zaman ortalamalı (a) $<\mathrm{u}>\mathrm{h}$ ız dağılımı (b) $<\mathrm{v}>$ hız dağılımı

Sonlu hacim yöntemi, bölümlerin her biri için bir çözüm bulmak üzere çözülecek geometriyi parçalara ayırma ve daha sonra soruna genel bir çözüm bulmak amacıyla bu çözümleri birleştirmek ilkesine dayanmaktadır. Bu yöntem, 1s1, akış denklemlerini sayısal olarak çözülebilen cebirsel denklemlere dönüştürmek için kontrol hacmine dayalı bir teknik kullanır. Diğger bir deyişle, bu teknik, her bir kontrol hacminde 1S1, akış denklemlerinin integrasyonunun alınması esasına dayanmaktadır. Bu integrasyon sonucu, oluşan her bir kontrol hacmini temsil eden denklemleri sağlar. En uygun ağ modelinin hazırlanması için hız, basınç ve sıcaklık gibi değişkenlerdeki değişimin daha büyük olduğu bölgelerde ince bir ağ yapısı oluşturulmalıdır. Bu nedenle, model binası çevresindeki hacim bölgeleri için en iyi ağ yapısı kullanılmış ve diğer bölgelerde daha seyrek bir ağ tercih edilmiştir. Sayısal çalışmada kullanılan $5 \mathrm{~cm} \times 5 \mathrm{~cm} \times 5 \mathrm{~cm}$ boyutlarındaki çatılı model 1381920 adet eleman içerirken, $5 \mathrm{~cm} \times 5 \mathrm{~cm} \times 10 \mathrm{~cm}$ boyutlarındaki çatılı model 1 734746 adet eleman içermektedir. Hesaplamaların yakınsaması, süreklilik ve momentum denklemleri için yakınsama ölçeği 10-6‘ dan küçük olduğunda, enerji denklemi için ise 10-7' den küçük olduğunda durdurulmuştur. Simülasyon için üç boyutlu piramitten oluşan ızgara yapısı kullanılmıştır (Şekil 11).

Bununla birlikte, sayısal model deneysel ortam koşulları kullanılarak gerçekleştirilmiştir. 0,193 $\mathrm{m} \mathrm{s}^{-1}$ akış hızı durumu için model etrafında üç boyutlu detaylı akış 
yapıları elde edilmiştir. Su kanalının girişinde ortalama türbülans yoğunluğu oldukça düşük olduğundan $(\% 0,5)$, sayısal çalışmada kanal girişinde düzgün hız profili, uœ uygulanmıştır. Çalışmada, bina çevresinde simetri ve duvar sınır koşulları kullanılmıştır. Kanal akışı için ise çıkış akışı sınır koşulundan yararlanılmıştır. Ayrıca, sayısal çalışmada binaların akışta türbülansa neden olması nedeniyle, aerodinamikte sıklıkla kullanılan k- $\varepsilon$ türbülans modeli kullanılırken akış alanının kanal için laminer olduğu varsayılmıştır.
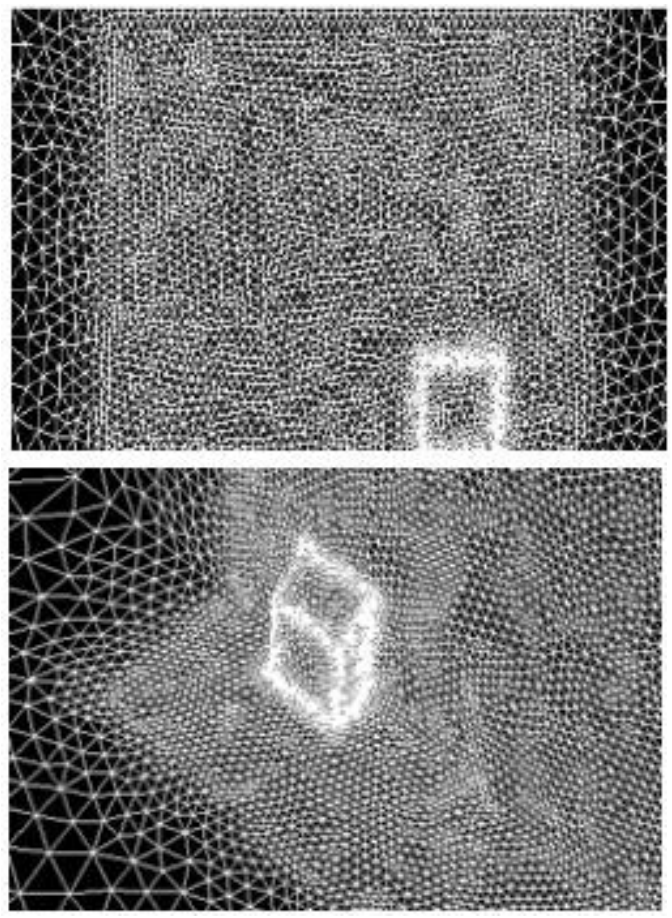

Şekil 11. Sayısal modellemede kullanılan ağ yapısı

Geometri boyunca akış ve 1sı transferi, kütle, momentum ve enerjinin korunumu yasalarından üretilen ve bir gövde kuvveti olmaksızın zamandan bağımsız olarak türetilen ve aşağıdaki gibi ifade edilen kısmi diferansiyel denklemler çözülerek elde edilmiştir ([12], [13], [14]). Süreklilik denklemi Eşitlik 1. , x, y ve z momentum denklemleri sırasıyla Eşitlik 2.1., 2.2. ve 2.3.' de gösterilirken, enerji denklemi Eşitlik 3. ile verilmektedir.

Süreklilik denklemi

$$
\frac{\partial u}{\partial x}+\frac{\partial v}{\partial y}+\frac{\partial w}{\partial z}=0
$$

Momentum denklemi

$\mathrm{x}$ momentum denklemi

$$
\begin{gathered}
\rho\left(u \frac{\partial u}{\partial x}+v \frac{\partial u}{\partial y}+w \frac{\partial u}{\partial z}\right)= \\
-\frac{\partial p}{d x}+\mu\left(\frac{\partial^{2} u}{\partial x^{2}}+\frac{\partial^{2} u}{\partial y^{2}}+\frac{\partial^{2} u}{\partial z^{2}}\right)
\end{gathered}
$$

y momentum denklemi

$$
\begin{gathered}
\rho\left(u \frac{\partial v}{\partial x}+v \frac{\partial v}{\partial y}+w \frac{\partial v}{\partial z}\right)= \\
-\frac{\partial p}{\partial y}+\mu\left(\frac{\partial^{2} v}{\partial x^{2}}+\frac{\partial^{2} v}{\partial y^{2}}+\frac{\partial^{2} v}{\partial z^{2}}\right)
\end{gathered}
$$

z momentum denklemi

$$
\begin{aligned}
& \rho\left(u \frac{\partial w}{\partial x}+v \frac{\partial w}{\partial y}+w \frac{\partial w}{\partial z}\right)= \\
& -\frac{\partial p}{\partial z}+\mu\left(\frac{\partial^{2} w}{\partial x^{2}}+\frac{\partial^{2} w}{\partial y^{2}}+\frac{\partial^{2} w}{\partial z^{2}}\right)
\end{aligned}
$$

Enerji denklemi

$$
u \frac{\partial T}{\partial x}+v \frac{\partial T}{\partial y}+w \frac{\partial T}{\partial z}=\left(\frac{k}{\rho c_{p}}\right)\left(\frac{\partial^{2} T}{\partial x^{2}}+\frac{\partial^{2} T}{\partial y^{2}}+\frac{\partial^{2} T}{\partial z^{2}}\right)
$$

Bu denklemlerde, $\rho$ yoğunluğu, $\mu$ dinamik viskoziteyi, $p$ basınc1, k 1sıl iletkenliği, T sicaklığı, $\mathrm{c}_{\mathrm{p}}$ özgül 1sıyı ve u, $\mathrm{v}, \mathrm{w}$ sırasıyla $\mathrm{x}, \mathrm{y}$ ve $\mathrm{z}$ yönlerindeki hızları göstermektedir.

Kullanılan standart $\mathrm{k}-\varepsilon$ türbülans modelinde, $\mathrm{k}^{\prime}$ türbülans kinetik enerji, $\in$ yayılma oranı ve $\phi$ viskoz dağılım terimidir. Bununla birlikte, Eşitlik 4.' de daimi akış türbülans kinetik enerji denklemi verilirken, Eşitlik 5. , 6. , 7. ve 8.' de sirasiyla türbülans viskozitesi, türbülans kinetik enerji, viskoz dağılım terimi ve türbülans kinetik enerji kaybolma denklemi gösterilmektedir.

Daimi akış türbülans kinetik enerji denklemi

$$
\begin{aligned}
& \frac{\partial\left(\rho u k^{\prime}\right)}{\partial x}+\frac{\partial\left(\rho v k^{\prime}\right)}{\partial y}+\frac{\partial\left(\rho w k^{\prime}\right)}{\partial z}= \\
& \frac{\partial}{\partial x}\left(\frac{\mu_{t}}{\sigma_{k}} \frac{\partial k^{\prime}}{\partial x}\right)+\frac{\partial}{\partial y}\left(\frac{\mu_{t}}{\sigma_{k}} \frac{\partial k^{\prime}}{\partial y}\right)+\frac{\partial}{\partial z}\left(\frac{\mu_{t}}{\sigma_{k}} \frac{\partial k^{\prime}}{\partial z}\right)+\mu_{t} \phi-\rho \varepsilon
\end{aligned}
$$

Türbülans viskozitesi

$$
\mu_{t}=C_{\mu} \rho \frac{k^{\prime 2}}{\varepsilon}
$$

Türbülans kinetik enerji

$$
k^{\prime}=\frac{1}{2}\left(\overline{u^{\prime 2}}+\overline{v^{\prime 2}}+\overline{w^{\prime 2}}\right)
$$

Viskoz dağılım terimi

$$
\begin{aligned}
& \phi=2 \mu\left[\left(\frac{\partial u}{\partial x}\right)^{2}+\left(\frac{\partial v}{\partial y}\right)^{2}+\left(\frac{\partial w}{\partial z}\right)^{2}\right]+ \\
& \mu\left[\left(\frac{\partial v}{\partial x}+\frac{\partial u}{\partial y}\right)^{2}+\left(\frac{\partial w}{\partial y}+\frac{\partial v}{\partial z}\right)^{2}+\left(\frac{\partial u}{\partial z}+\frac{\partial w}{\partial x}\right)^{2}\right]
\end{aligned}
$$


Türbülans kinetik enerji kaybolma denklemi

$$
\begin{aligned}
& \frac{\partial(\rho u \varepsilon)}{\partial x}+\frac{\partial(\rho v \varepsilon)}{\partial y}+\frac{\partial(\rho w \varepsilon)}{\partial z}= \\
& \frac{\partial}{\partial x}\left(\frac{\mu_{t}}{\sigma_{\varepsilon}} \frac{\partial \varepsilon}{\partial x}\right)+\frac{\partial}{\partial y}\left(\frac{\mu_{t}}{\sigma_{\varepsilon}} \frac{\partial \varepsilon}{\partial y}\right)+\frac{\partial}{\partial z}\left(\frac{\mu_{t}}{\sigma_{\varepsilon}} \frac{\partial \varepsilon}{\partial z}\right)+ \\
& C_{1 \varepsilon} \mu_{t} \frac{\varepsilon}{k^{\prime}} \phi-C_{2 \varepsilon} \rho \frac{\varepsilon^{2}}{k^{\prime}}
\end{aligned}
$$

Model sabitleri $C_{\mu}, C_{1 \varepsilon}, C_{2 \varepsilon}, \sigma_{k}$ ve $\sigma_{\varepsilon}$ standart k- $\varepsilon$ türbülans modeli için kullanılan varsayılan değerlerdir ([4], [6], [8]). Bu sabitlerin değerlerine, çok çeşitli türbülanslı akışlar için çok sayıda veri uydurma yinelemesi ile ulaşılmıştır. Bu sabitler şu şekildedir; $C_{\mu}=$ $0,09, C_{1 \varepsilon}=1,44, C_{2 \varepsilon}=1,92, \sigma_{k}=1$ ve $\sigma_{\varepsilon}=1,3$.

Şekil 12' de çatılı $5 \mathrm{~cm} \times 5 \mathrm{~cm} \times 5 \mathrm{~cm}$ boyutlarındaki bina modeli için bina ön, üst ve özellikle de arka bölgelerinde oluşan akış yapısını incelemek amacıyla zaman ortalamalı $<\mathrm{u}>$ hız bileşeninin kanal yüksekliğine göre değişimi boyutsuz deneysel ve sayısal olarak karşılaştırılmıştır. Şekil 12 incelendiğinde deneysel ve sayısal sonuçlar arasında bazı bölgelerde en yüksek \%3 farklılık olduğu görülmektedir. Bununla birlikte, bina arka bölgesinde oluşan hız profillerinin değiştiği belirlenmiştir. Bu durum, bina arkasında oluşan girdabın çatı etkisi nedeniyle büyüdüğünü göstermektedir. Ayrıca, z/H $=0,09$ profili parabolik bir değişim sergilemekle birlikte $\mathrm{z} / \mathrm{H}=0,45$ profilinden başlayarak ters akış oluşmuş ve $\mathrm{z} / \mathrm{H}=0,75$ profiline kadar azalarak devam etmiştir.

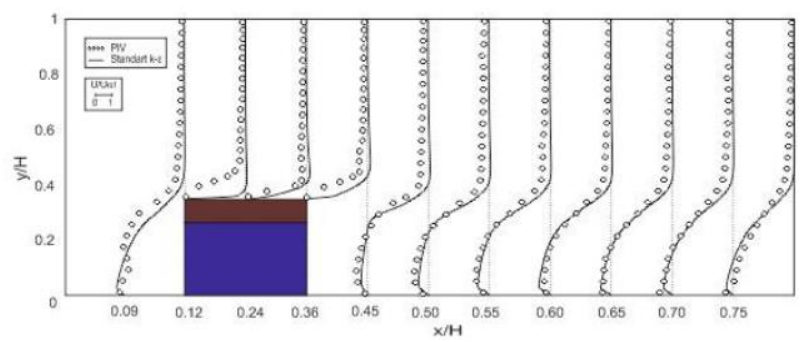

Sekil 12. Catıl1 $5 \mathrm{~cm} \times 5 \mathrm{~cm} \times 5 \mathrm{~cm}$ boyutlarındaki bir bina modeli için $\mathrm{z} / \mathrm{H}$ $=0,5$ simetri yüzeyinde $\mathrm{u} / \mathrm{U}_{\infty}$ hız profillerinin deneysel (PIV) ve sayısal (Standart k-E) olarak karşılaştırılması

$5 \mathrm{~cm} \times 5 \mathrm{~cm} \times 10 \mathrm{~cm}$ boyutlarında çatılı bina modeli için bina ön, üst ve arka bölgelerindeki zaman ortalamalı $<\mathrm{u}>\mathrm{h} 1 \mathrm{z}$ bileșeninin kanal yüksekliğine göre değişiminin boyutsuz deneysel ve sayısal olarak karşılaştırılması Şekil 13' de gösterilmektedir. Bu modelde bina üst bölgelerinde farklılık oluşmuş olmakla birlikte Şekil 12' de sunulan $5 \mathrm{~cm} \times 5 \mathrm{~cm} \times 5 \mathrm{~cm}$ boyutlarındaki bina modeline göre farklılığın azaldığı belirlenmiştir. Deneysel ve sayısal sonuçlar arasında bazı bölgelerde en fazla yalnızca $\% 2$ farklılık olduğu saptanmıştır. Bununla birlikte, $5 \mathrm{~cm} \times 5 \mathrm{~cm} \times 5 \mathrm{~cm}$ ölçülerindeki binanın arka bölgesinde oluşan hız profillerine benzer hız profillerinin oluştuğu ve bina arka bölgesinde ayrılmış akış profillerinin olduğu görülmektedir.

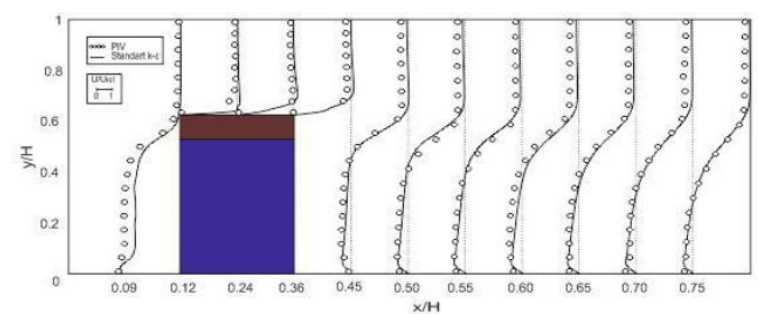

Şekil 13. Çatıl $15 \mathrm{~cm} \times 5 \mathrm{~cm} \times 10 \mathrm{~cm}$ boyutlarındaki bir bina modeli için $\mathrm{z} / \mathrm{H}=0,5$ simetri yüzeyinde $\mathrm{u} / \mathrm{U}_{\infty}$ hiz profillerinin deneysel (PIV) ve sayısal (Standart k-E) olarak karşılaştırılması

\section{GENEL SONUÇLAR VE DEĞERLENDİRME}

Bu çalışmada, bina merkezleri arası mesafenin $6,25 \mathrm{~cm}$ olduğu durumda $5 \mathrm{cmx} 5 \mathrm{~cm} \times 5 \mathrm{~cm}$ ve $5 \mathrm{cmx} 5 \mathrm{~cm} \times 10 \mathrm{~cm}$ boyutlarındaki binalar ile $10 \mathrm{~cm}$ olduğu durumda $5 \mathrm{~cm} \times 5 \mathrm{~cm} \times 10 \mathrm{~cm}$ boyutlarındaki çapraz olarak yerleştirilmiş üç adet çatılı bina modelinin etrafındaki akış yapıları deneysel olarak Parçacık Görüntülemeli Hız tekniği (PIV) kullanılarak karşılaştırmalı şekilde incelenmiştir. Ayrıca, $5 \mathrm{~cm} \times 5 \mathrm{~cm} \times 5 \mathrm{~cm}$ ve $5 \mathrm{~cm} \times 5 \mathrm{~cm} \times 10 \mathrm{~cm}$ boyutlarındaki çatılı binaların kanala tekil olarak yerleştirilmeleri durumundaki etraflarındaki akış yapılarının analizi sayısal olarak üç boyutlu, daimi, k- $\varepsilon$ türbülans modeli ile ANSYS Fluent bilgisayar programı kullanılarak ayrı ayrı yapılmış ve ulaşılan sayısal sonuçlar deneysel sonuçlarla karşılaştırılmıştır. Böylece, aşağıda belirtilen sonuçlara ulaşılmıştır.

1- Çatılı binalar arasında $6,25 \mathrm{~cm}$ mesafe bulunan durumlar için binaların yan kısımlarında ve bina arkalarındaki girdaplar incelendiğinde birbirlerine simetrik bir yapıda oldukları görülürken, $10 \mathrm{~cm}$ ' lik binalar aras1 mesafe olan durumda binaların yan kısımları ve bina arkalarındaki girdapların simetrik bir yapıda olmadıkları görülmektedir. Bu duruma, binalar arası mesafenin artmasıyla gelen akışın binaların köşe ve kenarlarından ayrılması sonucu yapıların yan duvarları boyunca ve arka kısmında oluşan ters akış bölgeleri sebep olmaktadır. $\mathrm{Bu}$ durumun sonucu olarak da girdapların olduğu bölgelerde akış hızında azalma görülmektedir.

2- Binaların akış ortamında bir arada bulunmaları, binalar etrafındaki akış yapılarının birbirleriyle karşılıklı etkileşim içerisinde bulunmalarına sebep olmaktadır. Bununla birlikte, binalar arası mesafeye bağlı olarak binalar arasında oluşan jet akış nedeniyle özellikle binalara yakın bölgelerde hızlar yükselmiş ve binalar arkasındaki girdap büyüklükleri değişiklik göstermiştir.

3- Binalar arası mesafenin $10 \mathrm{~cm}$ olduğu durumda, 6,25 $\mathrm{cm}$ olduğu duruma göre jet akış alanı genişlemiş ve buna bağlı olarak bina arka bölgelerinde farklı girdap yapıları oluşmuştur. Ayrıca, çapraz olarak yerleştirilen bina çevresindeki ayrılmış akış bölgesinin küçüldüğü görülmektedir.

4- $10 \mathrm{~cm}$ ' lik binalar arası mesafe durumunda arkadaki çapraz olarak yerleştirilen binanın ön bölgesindeki yukarı ve aşağı akış bölgelerinin mesafeleri artmıştır. 
5- Özellikle binalar arası mesafenin $6,25 \mathrm{~cm}$ olduğu durumda görülebildiği gibi çatı kısmından dolayı binanın arka tarafında ikincil bir ayrılmış akış bölgesi oluşmaktadır.

6- Deneysel ve sayısal sonuçlar arasında çatılı $5 \mathrm{~cm} \times 5 \mathrm{~cm} \times 5 \mathrm{~cm}$ boyutlarındaki kısa model için en fazla $\%$ 3' lük bir fark görülürken, $5 \mathrm{~cm} \times 5 \mathrm{~cm} \times 10 \mathrm{~cm}$ ölçülerindeki çatılı bina modeli için bu fark azalarak \%2 olarak belirlenmiştir. $\mathrm{Bu}$ farklılığa da bina üst kısımlarında oluşan girdaplar nedeniyle akışın değişkenlik göstermesinin sebep olduğu düşünülmektedir.

7- $5 \mathrm{~cm} \times 5 \mathrm{~cm} \times 5 \mathrm{~cm}$ boyutlarındaki çatılı bina için bina arkasında oluşan girdabın çatı etkisi nedeniyle büyüdüğü bina arka bölgesinde oluşan hı profillerinin değişiminden anlaşılmaktadır.

8- $5 \mathrm{~cm} \times 5 \mathrm{~cm} x 5 \mathrm{~cm}$ boyutlarındaki çatılı bina ile karşılaştırıldığında, $5 \mathrm{~cm} \times 5 \mathrm{~cm} \times 10 \mathrm{~cm}$ ölçülerindeki bina için bina arka bölgesinde oluşan hız profillerinin benzer olduğu ve bina arka bölgesinde ayrılmış akış profillerinin olduğu görülmektedir.

Sonuç olarak, binalar etrafında oluşan akış yapısına ve binalar üzerine etkiyen Rüzgâr kuvvetlerine, gelen Rüzgârın yönü ve şiddetinin yanı sıra binaların yerleşim planının, binalar arası mesafenin ve çatı kısmının da etkili olduğu görülmektedir.

\section{Teșekkür}

$\mathrm{Bu}$ çalışma, Sivas Cumhuriyet Üniversitesi Bilimsel Araştırma Projeleri (CÜBAP) birimi tarafından M-531 proje numarası ile desteklenmiştir.

\section{KAYNAKLAR}

[1] Gölbaşı D, Buyruk E, Şahin B, Karabulut K. Değişik bina modelleri için akış alanlarının deneysel ve sayisal olarak incelenmesi. Tesisat Müh. 2017; 6 (162): 32-47.

[2] Tutar M, Oguz G. Large eddy simulation of wind flow around parallel buildings with varying configurations, Fluid Dyn Res. 2002; 31 (5-6): 289315.

[3] Blocken B, Dezsö G, Beeck J, Carmeliet J. The mutual influence of two buildings on their wind driven rain exposure and comments on the obstruction factor. J Wind Eng Ind Aero. 2009; 97 (5-6):180-196.

[4] Chang XX, Zhao L, Ge YJ. High-Reynolds-number effects simulations for wind effects on a cooling tower model in a wind tunnel based on a statistical approach. J Brazi Soc Mech Sci Eng. 2021; 43 (99): 1-12.

[5] Huang P, Lin H, Gu M. Wind tunnel investigation of autorotation of plate: the effects of geometry, Reynolds number and rotation direction. J Wind Eng Ind Aerodyn. 2020; 196:104012.

[6] Liu Z, Cao S, Liu H, Hua X, Ishihara T. Effects of Reynolds number in the range from $1.6 \times 103$ to
$1.6 \times 106$ on the flow fields in tornado-like vortices by LES: a systematical study. J Wind Eng Ind Aerodyn. 2020; 196:104028.

[7] Gölbaşı D, Buyruk E, Karabulut K. Experimental and numerical research of the flow features around the building pairs with different types. Cumhuriyet Sci J. 2018; 39 (4): 1089-1106.

[8] Gölbaşı D, Buyruk E, Şahin B, Karabulut K, Kılınç F. Bina yüksekliği değişiminin akış yapıları üzerindeki etkisinin deneysel ve sayısal olarak incelenmesi. 21. Ulusal Isı Bilimi ve Tekniği Kongresi, ULİBTK'17. Çorum: 2017. p. 356-66.

[9] Daemei AB, Eghbali SR. Study on aerodynamic shape optimization of tall buildings using architectural modifications in order to reduce wake region. Wind Str. 2019; 29 (2): 139-147.

[10] Wheatley C, Baumann M, Gutierrez SM. Aerodynamic mitigation of origami-1nspired building structures subjected to hurricane wind loads. Behavior and Mechanics of Multifunctional Materials IX, Proc. SPIE 11377. Online: 2020. p. 1137708.

[11] Yan B, Li QS. Wind tunnel study of interference effects between twin super-tall buildings with aerodynamic modifications. J Wind Eng Ind Aero. 2016; 156: 129-145.

[12] Gölbaşı D. Yerleşim alanları içerisinde farklı geometrilere sahip yapılar üzerinde 1sı transferi ve akış yapılarının deneysel ve teorik olarak incelenmesi [Doktora Tezi]. Sivas: Sivas Cumhuriyet Üniversitesi; 2015.

[13] Gousseau P, Blocken B, Stathopoulos T, Heijst GJF. CFD simulation of near field pollutant dispersion on a high resolution grid: a case study by les and rans for a building group in downtown Montreal. Atm Env. 2011; 45 (2): 428-438.

[14] FLUENT. Fluent 6.1 user's guide. 2003; Fluent Inc., Lebanon. 